УДК 349.6

DOI https://doi.org/10.32838/1606-3716/2020.4/15

\title{
Шеховцов В.В.
}

Національний юридичний університет імені Ярослава Мудрого

\section{ТЕОРЕТИКО-МЕТОДОЛОГІЧНІ АСПЕКТИ ФОРМУВАННЯ СИСТЕМИ ФУНКЦИЙ УПРАВЛІННЯ У СФЕРІ РЕАЛІЗАЦІЇ ФАУНІСТИЧНИХ ПРАВОВІДНОСИН}

Статтю присвячено дослідженню теоретико-методологічних засад формування системи функиій екологічного управління та управління у сфері реалізачії фауністичних правовідносин із метою встановлення специфічних ознак і розроблення моделі структури функиій управління в галузі охорони, використання та відтворення тваринного світу.

У роботі встановлено, щзо ефективність здійснення функцій у сфері реалізації фауністичних правовідносин може досягатися лише шляхом утворення досконалої моделі управління у сфері охорони й використання тваринного світу, що є базовим питанням реформаиійних процесів у иій галузі.

Обтрунтовується теза про те, що різноманітність і множинність підходів до упорядкування функиій екологічного управління справляє безпосередній вплив $і$ на систему функиій управління, що притаманна фауністичній галузі, щодо якої спостерігається подекуди специфічний порядок ї̈ наповнення.

Зазначено, що процес становлення як функцій екологічного управління, так $і$ функцій управління у сфері охорони й використання тваринного світу перманентний, підвладний змінам, що відбуваються в навколишньому середовищі й екологічному законодавстві, й триває відповідно до вимог і приписів Європейського Союзу, щэо віднаходять своє поступове впровадження до законодавства України.

Зроблено висновок, що функиія екологічного управління позначається через категорії діяльності, впливу, обов'язку, призначення. Участь в екологічному управлінні бере й відповідний суб'єктний склад, щуо має провадити діяльність із конкретним призначенням - опіка над навколиинім природним середовищем.

Пропонується виділити основні функиії, притаманні управлінню у сфері охорони й використання тваринного світу, що випливають із повноважень органів управління в цій галузі: розподіл ресурсів фауни й фауністичне впорядкування; облік об'єктів тваринного світу; фауністичний моніторинг; прогнозування та планування у сфері охорони й використання тваринного світу; контроль у сфері охорони й використання тваринного світу; стандартизація та нормування в галузі охорони, використання та відтворення тваринного світу; функиія ліцензування та видачі дозволів на спеціальне використання об' 'кктів тваринного світу; функція фауністичного інформування.

Ключові слова: функції управління, екологічне управління, управління у сфері реалізації фауністичних правовідносин, фауністичне законодавство, охорона навколишнього природного середовища.

Постановка проблеми. Ефективність здійснення функцій у сфері реалізації фауністичних правовідносин може досягатися лише шляхом утворення досконалої моделі управління в сфері охорони й використання тваринного світу, що $\epsilon$ наразі проблемним, проте наскрізним та актуальним питанням, яке перебуває в процесі реалізації, або близьким до такого. Нестабільність організації й порядку інституційних моделей управління у сфері охорони та використання тваринного світу й екологічній сфері в цілому, обумовлює нестійкість та мінливість функціо- нального апарату та можливостей його реалізації органами управління.

Різноманітність i множинність підходів до упорядкування функцій екологічного управління справляє безпосередній вплив і на систему функцій управління, що притаманна фауністичній галузі, щодо якої спостерігається подекуди специфічний порядок їх наповнення.

Аналіз останніх досліджень та публікацій. Окремі науково-методологічні й класифікаційні аспекти формування функцій управління в галузі природокористування та охорони довкілля 
досліджувалися такими представниками вітчизняної еколого-правової науки, як В.I. Андрейцев, А.П. Гетьман, В.М. Завгородня, В.А. Зуєв, I.I. Каракаш, Н.Р. Кобецька, В.М. Комарницький, В.В. Костицький, Н.В. Кручиніна, І.О. Солошич, Ю.О. Цибульський, Ю.С. Шемшученко, В.М. Шмандій, М.В. Шульга й іншими вченими. Представлені дослідження більшою мірою характеризуються своєю комплексністю у підходах до розуміння, характеристики й систематизації функцій екологічного управління, що, безумовно, становить надзвичайну цінність для розвитку науки екологічного права. Втім, як можна побачити у роботі, єдиної методології в побудові системи функцій екологічного управління так і не досягнуто. Проблематика ж функцій управління в галузі охорони та використання тваринного світу є малодослідженою й становить свою самостійну актуальність зважаючи на специфічні особливості та значимість, яку отримують процеси їх реалізації у цій сфері.

Постановка завдання. Мета статті - на основі розробленої в науці екологічного права класифікації функцій екологічного управління встановити специфічні ознаки й запропонувати модель структури функцій управління в галузі охорони, використання та відтворення тваринного світу.

Виклад основного матеріалу дослідження. Функціональні відносини в фауністичній сфері становлять основу відносин управлінського характеру у цій галузі, адже працездатність інституційної системи управління забезпечується саме через оптимальну модель функціонального апарату та законодавчих можливостей по його реалізації. «Цілі управління досягаються в процесі виконання певних функцій» - зазначав В.А. Зуєв [9, с. 54]. В.Б. Авер'янов же підкреслював, що удосконалення глибинної підсистеми державноуправлінських відносин здійснюється через побудову та оновлення іншої підсистеми - функціональних відносин, які безпосередньо взаємодіють із державним управлінням [3, с. 418].

Процес становлення як функцій екологічного управління, так і функцій управління в сфері охорони та використання тваринного світу $є$ перманентним, підвладний змінам, що відбуваються у навколишньому середовищі та екологічному законодавстві i, як зазначається в літературі, - «триває відповідно до вимог та приписів ЄС» $[6$, с. 66]. Управління довкіллям та інтеграція екологічної політики в інші галузеві політики $\epsilon$ одним із ключових питань Угоди про асоціацію України та $Є С[17 ; 14 ; 4]$.
Категорії «функцій» в екологічному праві можуть мати різні наповнення й спрямування. Можна говорити про функції управління, екологічні функції, функції екосистем і так далі.

Значення цих термінів різняться:

- Функції екосистеми $є$ властивостями середовища проживання, біологічні чи системні процеси екосистем. Іншими словами, вони виражають внутрішнє функціонування екосистем через взаємодію між абіотичними та біотичними компонентами (рослинність, вода, грунт, атмосфера та біота), які опосередковують обмін енергією та речовинами всередині екосистем та між ними.

- Екологічна функція описує, наприклад, як взаємодіють особини різних видів в озері чи лісі, які тенденції можна віднайти в довгостроковій динаміці різних популяцій, загальній біомасі системи або потоці певних речовин всередині неї. Прикладом екологічної функції $\epsilon$, наприклад, сприяння тваринами запиленню рослин, що призводить до їх виживання та розмноження, або знищення хижаком популяції іншого виду на певній території. Таким чином, екологічну функцію можна вважати невеличкою частиною екосистеми в цілому.

- Функції екологічного управління в науковій літературі характеризують як:

- основні напрями організаційно-правового впливу на суспільні відносини в галузі охорони довкілля, раціонального використання природних ресурсів і забезпечення екологічної безпеки [10, c. 193];

- види діяльності державних органів виконавчої влади, місцевого самоврядування та громадських організацій по забезпеченню організації раціонального використання природних ресурсів, їх відтворення та захисту і охорони навколишнього середовища [5, с. 38];

- основні напрями діяльності органів державної виконавчої влади, місцевого самоврядування, громадських об'єднань щодо забезпечення організації раціонального використання природних ресурсів, їх відтворення і захисту, охорони навколишнього природного середовища та забезпечення екологічної безпеки [2, с. 57-58];

- основні напрямки діяльності відповідних суб'єктів щодо організації охорони довкілля $[11$, c. 86$]$;

- визначений у законодавчих та інших нормативно-правових актах напрям діяльності суб'єктів щодо організації охорони довкілля, забезпечення екологічної безпеки та використання та відтворення природних ресурсів [13, с. 126]. 
Таким чином, функція екологічного управління позначається через категорії діяльності, впливу, обов'язку, призначення. В тій або іншій мірі ці характеристики проявляються у визначеннях, напрацьованих юридичною науковою спільнотою. Крім того, як можна побачити, вчені пропонують до участі в екологічному управлінні відповідний суб'єктний склад, що має провадити діяльність із конкретним призначенням - опіка над навколишнім природнім середовищем.

На думку В.М. Завгородньої, доцільніше визначати функції управління природокористуванням і охороною довкілля саме як напрямки управлінської діяльності, що $є$ відносно відокремленими та включають в себе певні групи однорідних управлінських дій, об'єднаних за метою здійснення [8]. Можна цілком погодитися 3 авторкою у тому, що групування управлінських дій за напрямками на підставі їх однорідності $\epsilon$ цілком справедливим для формування системи функцій, але, в той же час, із визначення $\epsilon$ незрозумілим, чим тоді функції екологічного управління за своїми ознаками відрізняються від функцій управління взагалі.

Загальні напрями формування функцій екологічного управління передбачені ст. 16 Закону України «Про охорону навколишнього природного середовища» [16], де зазначається, що управління охороною навколишнього природного середовища полягає у здійсненні в цій галузі функцій спостереження, дослідження, стратегічної екологічної оцінки, оцінки впливу на довкілля, контролю, прогнозування, програмування, інформування та іншої виконавчо-розпорядчої діяльності.

Тож, законодавець визначив основні принципові напрями реалізації своїх повноважень для органів екологічного управління, надавши базовий перелік управлінських функцій. Наразі можна говорити саме про базовий, адже закон залишає можливості для здійснення іншої виконавчо-розпорядчої діяльності з метою здійснення управління у сфері охорони навколишнього природного середовища. Утім, такий підхід видається цілком виправданим, адже невичерпність переліку залишає можливості для вияву творчої і раціональної ініціативи виконавців, пошуків ефективних шляхів та способів досягнення цілей екологічного управління.

Закон України «Про тваринний світ» [15] перелік функцій управління в сфері охорони та використання тваринного світу прямим чином не визначає. Лише опосередковано ми можемо їх виділити 3 повноважень державних органів у галузі охорони, використання і відтворення тваринного світу. А отже, основне значення отримує Закон України «Про охорону навколишнього природного середовища» [16], який має у цьому відношенні більшу структурованість та визначеність.

Однак, хоча у Законі України «Про тваринний світ» [15] і відсутній перелік функцій управління у сфері реалізації фауністичних правовідносин, він має цінність у передбаченні і розподілі повноважень між органами управління у галузі охорони, використання і відтворення тваринного світу. Суб'єкти, що здійснюють управління у цій сфері, мають різний обсяг повноважень, від яких залежить і об'єм виконуваних ними функцій. Звісно що і палітра функцій в залежності від цього $є$ досить різнобарвною.

А.П. Гетьман, характеризуючи функції екологічного управління, використовує комплексний підхід до їх впорядкування. Серед останніх вчений виділяє такі функції як: просторово-територіальний устрій природних ресурсів, облік та кадастри природних ресурсів, екологічне прогнозування та планування, екологічний моніторинг, оцінка впливу на довкілля, стратегічна екологічна оцінка, екологічний контроль, екологічне інформаційне забезпечення, екологічна стандартизація та нормування, екологічне ліцензування [6, с. 67-87]. Іноді науковці йдуть шляхом групування функцій екологічного управління за певними ознаками, здійснюючи їх класифікацію. Той же А.П. Гетьман у співавторстві з М.В. Шульгою здійснюють таке групування за предметною спрямованістю. Вони здійснюють поділ функцій управління у сфері природокористування й охорони довкілля на організаційні (облік, планування, прогнозування, розподіл та перерозподіл природних ресурсів тощо), попереджувально-охоронні (моніторинг, контроль, екологічна експертиза) та інші (екологічне інформування, стандартизація і нормування) [5, с. 52-65].

Також функції управління у сфері охорони навколишнього природного середовища поділяють на загальні, що властиві державному управлінню в цілому (прогнозування, планування), і спеціальні, що характерні для цієї сфери управління (облік природних ресурсів, лімітування та нормування тощо) [7, с. 157-158]. Схожого підходу притримуються і В.М. Шмандій та I.О. Солошич, відносячи до загальних функції законодавчого регулювання, прогнозування, планування, організації, координації, погодження, контролю і нагляду, а до спеціальних: біовпровадження, ресурсовпровадження, розподілу і перерозподілу природних ресурсів, обліку 
природних ресурсів, спеціалізованого контролю, лімітування скидів, експертизи, моніторингу, вирішення спорів, забезпечення відповідальності за екологічні правопорушення, стандартизацію, аудит, сертифікацію, ліцензування, страхування, організацію освіти, інформування, постійного вдосконалення управління [19, с. 50-54]. В останньому впорядкуванні, не применшуючи значення кожної із наведених функцій, все ж варто сказати про збільшену їх деталізацію та доцільність об’єднання й уніфікації деяких із них задля більш гармонійної узгодженості. Подібну структуру пропонував i B.I. Андрейцев, поділяючи функції екологічного управління на загальні (організація, координація, погодження та контроль) і спеціальні (прогнозування, стандартизація, нормування, ліцензування, лімітування, організація експертизи, екологічне інформування, ведення природноресурсових кадастрів і Червоної книги, територіальне і ресурсовпорядне планування, розподіл і перерозподіл природних ресурсів, а також розв'язання спорів) [1, с. 116]. Таким чином, як можна побачити, значна кількість розробок характеризується дихотомічним поділом при групуванні функцій екологічного управління.

Та разом із цим, велика кількість досліджень зупиняється на використанні лінійного способу поділу визначення функцій органів управління, котрий, на переконання В.М. Комарницького, дозволяє послідовно розглянути весь ряд функцій, які $є$ визначальними для управління у сфері природокористування [12, с. 192]. Перелік і спосіб позначення таких функцій є подібним до використовуваного А.П. Гетьманом [6, с. 67-87], Ю.С. Шемшученком [18].

Таким чином, як функції екологічного управління у сукупності, так і функції екологічного контролю, екологічного моніторингу, оцінки впливу на довкілля, екологічного прогнозування тощо, ставали предметом багатьох досліджень в науці екологічного права зокрема й через те системне значення, яке вони відіграють у формуванні ланцюгових зв'язків між ii окремими інститутами. Неабияку цінність вони мають i для механізму управління при їх реалізації в сфері охорони та використання тваринного світу, адже взаємообумовленість фауністичного права 3 іншими структурними елементами еко- логічного - підтверджується практичною неможливістю комплексної охорони та використання тваринного світу без застосування норм та інститутів інших підгалузей. Наприклад, реалізація державної екологічної політики у сфері охорони тваринного світу передбачає розробку організаційно-правових заходів, спрямованих на забезпечення збереження не лише диких тварин, але й середовищ їх існування та шляхів міграції, що демонструє нерозривний корелятивний зв'язок із ландшафтним, флористичним, водним правом як підгалузями екологічного права. Застосування нормативно-правових положень, які регулюють процедуру формування екологічної мережі та створення природно-заповідних територій, як одного із інструментів охорони тваринного світу, орієнтує на взаємопроникнення норм фауністичного та природно-заповідного права. А отже, підходи, що можуть використовуватися для розгляду правових категорій, об'єднаних загальним предметом, можуть і повинні мати спільні напрями їх характеристики і дослідження.

Висновки i перспективи. Використовуючи популярний у науковій сфері лінійний спосіб поділу функцій екологічного управління, можна виділити основні функції, притаманні управлінню у сфері охорони й використання тваринного світу, що випливають із повноважень органів управління в цій галузі: розподіл ресурсів фауни й фауністичне впорядкування; облік об'єктів тваринного світу; фауністичний моніторинг; прогнозування та планування у сфері охорони й використання тваринного світу; контроль у сфері охорони й використання тваринного світу; стандартизація та нормування в галузі охорони, використання та відтворення тваринного світу; функція ліцензування та видачі дозволів на спеціальне використання об'єктів тваринного світу; функція фауністичного інформування. Реалізація ж названих функцій є вагомим способом впливу на фауністичні правовідносини в інтересах забезпечення сталого розвитку й раціонального використання природних ресурсів.

Перспективою подальших досліджень є розроблення методологічної основи побудови й визначення законодавчих можливостей і перспектив здійснення кожної окремої функції управління у сфері реалізації фауністичних правовідносин.

\section{Список літератури:}

1. Андрейцев В.І. Екологічне право : навчальний посібник. Київ : Вентурі, 1996. 208 с.

2. Гетьман А.П. Правові основи управління природокористуванням і охороною навколишнього природного середовища (екологічне управління). Екологічне право Украӥни : підручник для студентів юридичних спеціальних навчальних закладів. Харків : Право, 2013. С. 37-71. 
3. Державне управління : підручник : у 2 т. / Нац. акад. держ. упр. при Президентові України ; ред. кол. : Ю.В. Ковбасюк, К.О. Ващенко, Ю.П. Сурмін та ін. Київ ; Дніпропетровськ : НАДУ, 2012. Т. 1. 564 с.

4. Доповідь Платформи громадянського суспільства Україна-СС, Брюссель, 18 травня 2017 року. URL: https://www.civic-synergy.org.ua/wp-content/uploads/2018/04/Dovkillia-Fin-6.pdf (дата звернення: 09.04.2020).

5. Екологічне право України : підручник / за ред. А.П. Гетьмана і М.В. Шульги. Харків : Право, 2005. $384 \mathrm{c}$.

6. Екологічне право : підручник / А.П. Гетьман, Г.В. Анісімова, А.К. Соколова та ін. ; за ред. А.П. Гетьмана. Харків : Право, 2019. 552 с.

7. Екологічне управління : підручник / В.Я. Шевчук, Ю.М. Саталкін, Г.О. Білявський та ін. Київ : Либідь, 2004. 432 с.

8. Завгородня В.М. Система і класифікація функцій державного управління у сфері природокористування і охорони довкілля. URL: https:/essuir.sumdu.edu.ua/bitstream-download/123456789/57560/6/ Zavgorodny_2011.pdf;jsessionid=544E8FCF8F66F0FBE077268B65C78F7F (дата звернення: 03.04.2020).

9. Зуєв В.А. Організаційно-правові аспекти природокористування та охорони навколишнього природного середовища : дис. ... канд. юрид. наук : 12.00.06. Харків, 2002. 215 с.

10. Каракаш I.I. Правові засади управління і контролю у сфері природокористування й охорони навколишнього природного середовища. Екологічне право Украйни : підручник для студентів вищих навчальних закладів / за ред. І.І. Каракаша. Одеса : Фенікс, 2012. С. 182-208.

11. Кобецька Н.Р. Екологічне право України : навчальний посібник. Київ : Юрінком Інтер, 2007. 352 с.

12. Комарницький В.М. Правове забезпечення функцій державного управління у сфері природокористування. Вісник Луганського державного університету внутрішніх справ ім. Е.О. Дідоренка. 2010. № 1. C. 191-199.

13. Комарницький В.М., Шевченко В.І., Слькін С.В. Екологічне право : навчальний посібник. 3-є вид. Київ : Центр навчальної літератури, 2006. 224 с.

14. Про затвердження Плану заходів з імплементації Угоди про асоціацію між Україною та ЄС на 2014-2017 роки : Розпорядження Кабінету Міністрів України від 17 вересня 2014 року № 847-р / Верховна Рада України. URL: http://zakon5.rada.gov.ua/laws/show/847-2014-p (дата звернення: 16.07.2020).

15. Про тваринний світ : Закон України від 13 грудня 2001 року №2894_III / Верховна Рада Украӥни. Голос Украӥни. 2002. 16 січня (№ 9).

16. Про охорону навколишнього природного середовища : Закон України від 07 червня 2020 року № 1264-XII / Верховна Рада Украӥни. Відомості Верховної Ради Украӥни. 1991. № 41. Ст. 546.

17. Угода про асоціацію між Україною, з однієї сторони, та Європейським Союзом, Європейським співтовариством з атомної енергії і їхніми державами-членами, з іншої сторони. Офіційний вісник України. 26 вересня 2014 року. № 75. Том 1. Стор. 83. Ст. 2125.

18. Шемшученко Ю.С. Правовые проблемы экологии / АН УССР. Ин-т государства и права ; отв. ред. В.Л. Мунтян. Киев : Наукова думка, 1989. 232 с.

19. Шмандій В.М., Солошич I.О. Управління природоохоронною діяльністю : навчальний посібник. Київ : Центр навчальної літератури, 2004. 296 с.

\section{Shekhovtsov V.V. THEORETICAL AND METHODOLOGICAL ASPECTS OF THE FORMATION OF THE SYSTEM OF MANAGEMENT FUNCTIONS IN THE SPHERE OF IMPLEMENTATION OF FAUNISTIC RELATIONS}

The article is devoted to the study of theoretical and methodological principles of formation of the system of functions of ecological management and management in the field of faunal legal relations in order to establish specific features and develop a model of management functions in the field of protection, use and reproduction of wildlife.

The paper establishes that the effectiveness of the implementation of functions in the implementation of faunal legal relations can be achieved only by creating a perfect model of management in the field of protection and use of wildlife, which is a basic issue of reform processes in this area.

The thesis is substantiated that the diversity and multiplicity of approaches to streamlining the functions of environmental management has a direct impact on the system of management functions, which is inherent in the faunal industry, for which there is a specific order of their filling.

It is established that the process of formation of both environmental management and management functions in the field of protection and use of wildlife is permanent, subject to changes in the environment and environmental legislation and continues in accordance with EU requirements and regulations, which are gradually being implemented into the legislation of Ukraine. 
It is concluded that the function of environmental management is affected by the categories of activities, influences, responsibilities, purposes. Relevant entities that must carry out activities for a specific purposecare for the environment - also take part in environmental management.

It is proposed to highlight the main functions inherent in the management of the protection and use of wildlife, arising from the powers of government in this area: the distribution of fauna resources and faunal ordering; accounting of objects of the animal world; faunal monitoring; forecasting and planning in the field of protection and use of wildlife; control in the field of protection and use of wildlife; standardization and regulation in the field of protection, use and reproduction of wildlife; the function of licensing and issuing permits for special use of wildlife; function of faunal information.

Key words: management functions, ecological management, management in the field of realization of faunal legal relations, faunal legislation, environmental protection. 